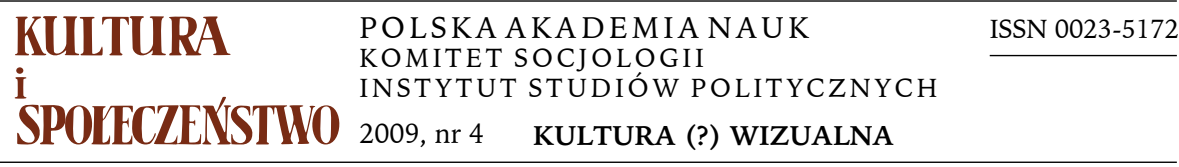

TOMASZ FERENC, BOGUSŁAW SUŁKOWSKI

Uniwersytet Łódzki

\title{
OKIEM KAMERY — SEMIOLOGIA OBRAZÓW PRZEMOCY
}

\section{KAMERA W NOWEJ SYTUACJI SPOŁECZNEJ}

Termin „przemoc” w najbardziej oczywisty sposób odnosi się do wszelkich aktów fizycznej agresji, związanych z zadaniem cierpienia, zranieniem, uśmierceniem lub upokorzeniem. Jednak równie często używamy tego terminu do nazwania czynów o charakterze pozafizycznym, takich jak przemoc symboliczna, na przykład mowa nienawiści (hate speech), przemoc psychiczna, albo interesująca nas przemoc wizualna, w tym przypadku rejestrowana okiem kamery ${ }^{1}$. W kontekście refleksji nad taką formą przemocy istotne jest także pytanie o intencjonalność wykorzystania technik i materiałów wizualnych. Dlatego też przemoc wizualną, $\mathrm{z}$ użyciem kamery (fotografii, filmu, internetu), rozpatrujemy $w$ trzech płaszczyznach: jako epatowanie obrazami okrucieństwa, jako sam akt agresywnego fotografowania i filmowania (np. nieposzanowanie prywatności) oraz jako każde inne wykorzystanie obrazu, gdy staje się on narzędziem gwałtu symbolicznego. Ten ostatni przypadek może dotyczyć wielu fotografii, które dopiero przez wtórne ich zastosowanie zyskują funkcję opresyjną. Analizy zjawiska przemocy wizualnej weszły w nowy etap wraz z nastaniem ery mediów elektronicznych, ponieważ wszechobecność obrazów, ich dostępność oraz szybkość transferu odmieniły całkowicie dzisiejszą ikonosferę. Zwraca na to uwagę Krzysztof Olechnicki (2009, s. 8), gdy pisze, że nastąpił Blitzkrieg fotografii cyfrowej, która nie tylko umasowiła dostępność do środków wizualnej rejestracji, ale i spowodowała ich wielowymiarowe wyzwolenie spod kontroli społecznej, w tym także spod władzy tradycyjnych wartości

Adres do korespondencji: tomasz.ferenc@wp.pl

${ }^{1}$ Interesujące nas zjawisko bywa także określane terminem przemocy ikonicznej; zob. Wilk 2001; Ogonowska 2004. 
etycznych i estetycznych. Należy odróżnić przemoc fotografowania i filmowania od przemocy, jaką niesie ze sobą lub jaką wywołuje sam utrwalony mechanicznie obraz. Fotografowanie lub filmowanie może stać się formą napaści, wtargnięciem w cudzą prywatność, może zbliżyć się do czynnej formy agresji. W takich przypadkach często przywoływane są działania fotoreporterów, a o wiele częściej paparazzi. Dziś każdy z nas jest narażony na taką formę napaści, zwłaszcza gdy aparat fotograficzny za sprawą telefonii komórkowej stał się najpopularniejszym z masowych gadżetów, umożliwiającym utrwalanie nie tylko zdjęć, ale także krótkich filmów. Taką formę agresji mogą przejawiać także artyści, i to w trzech odmianach — agresji skierowanej w stronę fotografowanych (np. wielokrotnie wspominany „ostry” styl pracy Diany Arbus), agresji zwróconej w stronę widza (fotografie Joela-Petera Witkina, Andresa Serrano) oraz destruktywnej autoagresji (prace Davida Nebredy, Franceski Woodman). Możemy zatem mówić o czynności fotografowania i filmowania, która zyskuje znamiona przemocy, a także o samej zarejestrowanej przemocy, o artefakcie, $z$ którym konfrontowany jest odbiorca. W pierwszym przypadku ofiarą staje się fotografowany, w drugim oglądający. W specyficznych sytuacjach rejestrowania aktów autoagresji przemocą zostają dotknięci zarówno autorzy zdjęcia, jak i jego odbiorcy. Ci pierwsi doświadczają realnie zadanego sobie bólu, drudzy stają się ofiarami przemocy wizualnej, doznają urazu emocjonalnego. Wreszcie możemy mówić także o przemocy, jaką niesie ze sobą pozornie niewinna fotografia komercyjna. Jest ona istotnym narzędziem przemocy symbolicznej, wpływa na wzory zachowań, wymusza przyjmowanie określonych postaw, dyktuje dominujące style w skali globalnej.

Mechaniczna i cyfrowa produkcja obrazów w swej zmysłowej konkretności stwarza wrażenie głębokiego wnikania w materię życia. Obraz jest odbiciem, dowodem na istnienie rzeczy samej. Ale oko kamery może mnożyć i mylić kilka różnych interpretacji rzeczywistości, a co ważniejsze, fotografia, inaczej niż pismo, nie ma właściwości wymuszania poznawczej interpretacji tego, co pokazuje. Dzisiejszy natłok obrazów i spektakli tworzy nową postawę widza nieinterpretującego, a czasem reportera lub artysty nieinterpretującego. Może istnieć fascynująca, rozbudowana ikonografia bez interpretującej ikonologii, może też być tworzona ikonografia będąca fałszywą namiastką rzeczywistości. Komunikat wizualny może komplikować funkcję matajęzykowego kodu bez eksponowania funkcji referencyjnej. W odniesieniu jednak do obrazów przemocy zanik funkcji referencyjnej nabiera wymiaru etycznego, twórca takich obrazów i jego odbiorcy stają wobec dylematów moralnych. W jakim stopniu dzisiejsza bujnie rozkwitła ikonosfera okrucieństwa zagrożona jest implozją sensu, zanikaniem treści? Czy we współczesnej kulturze ikonografie gwałtownego czynu tworzone są za sprawą postawy mniej czy bardziej skrywanej adiaforyzacji, czy przeciwnie - dowodzą realnej intencji przeciwstawienia się przemocy? Czy nowa sytuacja konsumentów medialnych rodzi nową populację osobników metaforycznie nazwanych przez Ericha Fromma (1998) charakterami nekrofilnymi? 
Czy obfite dokumentacje cierpienia innych, odległych i obcych wzmacniają empatię z nimi, czy też mają jakiś jeszcze inny niepożądany efekt społeczny? Chcemy tych problemów dotknąć na wybranych przykładach fotografowania i filmowania przemocy. Wobec istnienia sprzecznych opinii i deficytu rozstrzygających teorii sięgniemy do szczegółowych egzemplifikacji i zwrócimy się ku podejściu analitycznemu. Skupimy się nie na psychologii społecznej, lecz na wybranych produkcjach medialnych, które mogłyby mieć takie czy inne efekty społeczne.

Historia zmasowanego wkroczenia gwałtownych i drastycznych obrazów w wizualne spectrum współczesnego świata rozpoczęła się wraz z wynalezieniem fotografii. Używanie kamery prowadzi do powstania relacji łowca-ofiara. Chyba najbardziej popularną stała się metafora Susan Sontang, która przyrównała robienie zdjęć do strzelania. Amerykańska autorka sformułowała nośną tezę o immanentnej cesze fotografii, jaką jest agresja. Idąc tym tropem można by dowodzić, że fotografia od samego początku jest związana $z$ rejestrowaniem aktów przemocy. Tak było z pierwszym w historii zdjęciem ukazującym sytuację wykreowaną, fotografią Hippolyte'a Bayarda z 1840 r., zatytułowaną Autoportret topielca. Autor tej fotografii upozował się na samobójcę, czyli człowieka, który dokonał na sobie skrajnego aktu autoagresji. Za inny przykład może posłużyć jeden z pierwszych w historii fotoreportaży, wykonany 7 lipca $1865 \mathrm{r}$. przez Alexandra Gardnera, będący dokumentacją egzekucji na niedoszłych zabójcach prezydenta Stanów Zjednoczonych Abrahama Lincolna. Związki fotografii i przemocy wydają się immanentne i wieloaspektowe. Również teoretycy filmu, na przykład Siegfried Kracauer, dostrzegali genetyczną więź filmu z przemocą - kino i pistolet zostały dla siebie stworzone. Dzisiaj zjawisko nadmiaru obrazów medialnej przemocy zaczęto opisywać terminami takimi jak pornografia śmierci, tzw. ultraviolence czy komercjalizacja cierpienia. Z tym ostatnim można powiązać koncepcję kultury okrucieństwa, przez Marka Krajewskiego (2003, s. 127) uznanej za jedną z manifestacji współczesnych trendów popkulturowych. Tak rozumiane produkty kulturowe ukazują przemoc nie po to, by dyscyplinować jednostkę i przestrzegać ją przed społecznymi patologiami, ale by przyciągnąć uwagę widzów, dostarczając im rozrywki. Okrucieństwo traktowane $\mathrm{w}$ ten sposób zostaje pozbawione kontekstu moralnego, zyskuje zaś jedynie wymiar estetyczny.

Oczywiście przedstawienia ukazujące przemoc były znane i rozpowszechniane już dużo wcześniej, dzięki technikom drukarskim, chociażby takim jak litografia. Jednak dopiero fotografia dostarczyła obrazom nowej, do tej pory nie znanej ontycznej autentyczności. Nieostre, zamazane i pozbawiane szczegółów ujęcie fotograficzne będzie odbierane jako bardziej wiarygodne niż precyzyjny, hiperrealistyczny obraz ukazujący to samo wydarzenie. Siła fotografii wciąż opiera się na tych samych psychicznych aspektach oddziaływania obrazów mechanicznych - stworzeniu iluzji autentyczności, naoczności świadka, bezpośredniej relacji między zarejestrowanym obrazem a prefotograficzną sytuacją. 


\section{ARTYŚCI OKRUTNEJ FOTOGRAFII}

Przemoc wizualna w fotografii artystycznej może wystąpić, gdy artysta sam zwraca się przeciw sobie w akcie, mniej lub bardziej, kontrolowanej autodestrukcji. Mamy wówczas do czynienia z drastycznymi obrazami, których kontemplacja staje się doznaniem przykrym, nieraz szokującym. Artystyczna strategia szoku, transgresji i opresji wymusza na widzu doświadczenie łączące wrażenia estetyczne $z$ odrazą, strachem i głęboką przykrością. Za przykład niech posłużą tu działania dwóch artystów: Amerykanina Joela-Petera Witkina oraz Hiszpana Davida Nebredy ${ }^{2}$. Prace obu, choć różne pod względem formalnym, są boleśnie drastyczne, a jednocześnie niezwykle atrakcyjne wizualnie.

Witkin w swojej sztuce kreuje oniryczne światy, ale są to sny pełne perwersji, szokującego erotyzmu, przełamujące wszelkie tematy tabu. „Chcę aby moje zdjęcia były tak potężne, jak ostatnia rzecz jaką człowiek widzi lub zapamiętuje przed śmiercią" - pisze Witkin (1995) we wstępie do swojego albumu. Ikonograficzny repertuar tematów podejmowanych przez tego twórcę jest w znacznym stopniu mortualny lub nasycony niepokojącą seksualnością. Na poziomie preikonicznym pojawiają się martwe ciała bądź ich amputowane fragmenty, ludzkie płody, spreparowane zwierzęta. Pozujący modele są okaleczeni bądź dysfunkcjonalni od urodzenia. Ikonologiczna scenografia prac często nawiązuje do płócien wielkich mistrzów, identyfikacja tych motywów buduje ikonologię aluzji i dyskursu Witkina ze starymi mistrzami. W jego pracach znajdziemy bezpośrednie nawiązania do dzieł malarzy, między innymi takich jak Arcimboldo, Rubens, Caravaggio, Rembrandt, Goya, Canova, Bosch, Velázquez, Tycjan, Ribera, a także fotografów - głównie Augusta Sandera. Na Witkina wpływ mieli także twórcy komiksów, w których łatwym, choć ogólnikowym przesłaniem jest odwieczna walka dobra ze złem, personifikowana przez bohaterów amerykańskiej komiksowej mitologii. Estetyzacja gwałtu na fotografiach Witkina ma wymiar zbliżony do estetyzacji dokonywanej przez Hieronima Boscha. Dzieła starego mistrza także szokują, nie zatrzymując się jednak na epatującej ikonografii, przerażenie służy czemuś więcej. Siła dzieł amerykańskiego artysty wynika $\mathrm{w}$ dużej mierze $\mathrm{z}$ tego, że pracuje on $\mathrm{w}$ materii fotograficznej, która stanowi podstawowy wizualny język współczesności. Artysta ten dokonuje estetyzacji dalekiej od wszelkiego wizualnego hedonizmu. Nie jest to prosta zamiana tego, co odrzucone, w to, co estetyczne. Istotą jego prac nie jest dostarczenie przyjemności, lecz wywołanie szoku. Ar-

2 Do największych prowokatorów i obrazoburców w świecie sztuki należy Andres Serrano, jeden $z$ jego fotograficznych projektów został zrealizowany w kostnicy. Wielkoformatowe zdjęcia zmarłych wstawił $\mathrm{w}$ publiczną przestrzeń galerii, czyniąc $\mathrm{z}$ martwych ciał obiekty estetyczne. Jedna z najbardziej kontrowersyjnych prac, zatytułowana Piss Christ (Chrystus w urynie), wywołała skandal w Stanach Zjednoczonych, a w Polsce została zdjęta z wystawy zorganizowanej w CSW w $1994 \mathrm{r}$. 
tystyczny gest fotografa ma dalej idące konsekwencje, jest próbą włączenia „zakazanego" w obszar sztuki, co przybiera formy transgresyjne, gwałtowne i agresywne.

Hiszpański artysta David Nebreda konfrontuje odbiorcę swoich prac z ekstremalną autoprzemocą i kaźnią. Ten cierpiący na paranoidalną schizofrenię fotograf nieustanie okalecza własne ciało, a akty autodestrukcji uwiecznia na fotografiach. Jako adept Królewskiej Akademii Sztuk Pięknych w Madrycie uzyskał gruntowne przygotowanie artystyczne, dlatego jego prace są doskonale zakomponowane i wykonane, nie ma w nich przypadkowości czy histerycznej rejestracji własnych ran i cierpienia. Ikonograficzna kompozycja eksponuje formę dzieła. „Fotografie Nebredy są niezwykle malarskie i wystylizowane, urzekają kolorem, są z pietyzmem oświetlone, aby żaden makabryczny szczegół nie umknął uwadze odbiorcy" (Witkowska 2007, s. 114). Okaleczone i zagłodzone ciało artysty staje się jego narzędziem ekspresji i głównym tematem. Odbiorca musi znieść widok krwi, ekskrementów, ran spowodowanych nacinaniem, kłuciem, oparzeniem oraz anorektycznego wycieńczenia spowodowanego długotrwałym głodem. Artysta dokonuje transgresji, dostarczając widzom precyzyjnych świadectw swoich autoagresywnych działań. Ten rodzaj wizualnej przemocy jest niezwykle poruszający. Oglądając fotografie tego artysty wiemy, że zarejestrowany ból był faktycznie doświadczony przez autora i w tym sensie dzieło jest uczciwe i prawdziwe. Może właśnie te drastyczne gesty przywracają wiarygodność fotografii (sztuki), a doznany przez odbiorcę szok pełni rolę katarktyczną. Czy walka o przywrócenie dokumentacyjnej roli fotografii ma być jedynym przesłaniem tej twórczości? W jakim kierunku może być jeszcze rozwijana ta ikonologia makabry?

Dwa przytoczone przykłady artystów fotografii łączy intencja znacznie rozwiniętej estetyzacji przemocy i tortury. Każdy obraz gwałtu i autodestrukcji podlega opracowaniu kompozycji, manipuluje nastrojem, wymaga od widza zastanowienia i kontemplacji. Dlatego zdaniem Sławomira Magali (1982, s. 125) podobne fotografie mimo wszystko pełnią bardziej funkcję „przyjemnościową" niż „wstrząsową”: „[...] szczególna, osobliwa pozycja fotografii bierze się stąd, że nawet najbardziej wstrząsające zdjęcia dostarczają przyjemności estetycznej, której nie burzy nawet drastyczna i bardzo poważna treść "przekazu» komunikatu zdjęciowego". Zjawisko to określa on mianem hedonizmu estetycznego, ale czy w świetle potocznego, niekwalifikowanego doświadczenia odbiorczego do końca wierzyć będziemy w ów estetyczny hedonizm? Hedonistyczne koncepcje sztuki w estetyce konkurują z kilkoma innymi doktrynami. $Z$ pewnością możemy powiedzieć, że omawiani artyści doskonale posługują się ikonicznymi kodami okrucieństwa. Czy w tym wypadku odczucie szoku, strachu i odrazy $\mathrm{w}$ postawie odbiorcy nie bierze góry nad funkcją estetyczną? Wyszukana ikonografia, szokujące detale i motywy, estetyka przełamująca tabu są tu skutecznymi narzędziami rozwijania zagadkowej interpretacji ikonologicznej, wyrafinowany naturalizm służy pomnażaniu pokładów metafory. 


\section{PRAKTYKI KINA KOMERCYJNEGO I ARTYSTYCZNEGO}

W sztuce fotografii obrazy tortury, eksperymentowanie ze śmiercią i to, co w krytyce nazywa się ultraviolence, są spotykane względnie często, na gruncie fotografii wciąż eksploatuje się jakieś społecznie odczuwane jeszcze ostatnie tabu. Podobnie współczesny teatr tak zwanych nowych brutalistów prowokacyjnie atakuje bezpośrednim widokiem krwawiącego ciała, ekskrementami, ekshibicjonizmem fizycznym i psychicznym. Na gruncie filmowych fikcji fabularnych wątki śmierci i tortury ustabilizowały swą estetyczną stylistykę już gdzieś w drugiej połowie minionego wieku (Sułkowski 2007, s. 24-59). W filmach amerykańskich eksperymentowano wówczas z fotografowaniem tortury, filmowano tak zwaną kreatywną śmierć, wyniszczającą wojnę komponowano do muzyki Wagnera i ostatecznie przełamano tabu niepatrzenia $\mathrm{w}$ twarz konającego. Trudno dziś wymyślić w tej kwestii coś naprawdę nowego poza postmodernistycznymi grami i aluzjami gatunkowymi, zresztą i to praktykowano w latach osiemdziesiątych XX wieku. Z tamtych lat pochodzą też najbardziej rozwinięte statystyczne badania obrazów okrucieństwa. Analiza próbek filmowanych aktów przemocy pozwoliła wskazać ich najbardziej destrukcyjne cechy, takie jak: ujmowanie ataków na cielesność człowieka $w$ realiach niebezpiecznie naturalnych, realistycznych, detaliczne, przeciągające się w czasie fotografowanie technologii zabijania, celebrowanie tortury $z$ użyciem piły łańcuchowej, imadła itd., erotyzująca pornografia kaźni, liczne ujęcia na zbliżeniu zdewastowanego ludzkiego korpusu lub wyrwanych, poszarpanych części ciała. Spalona twarz jest ujęciem powtarzalnym w kinie akcji i kinie gangsterskim, z czym konkurują takie motywy preikoniczne jak świeżo odcięta, jeszcze poruszająca palcami ręka, spływające oko, mózg na słupie kolejowym, wnętrzności najrozmaiciej fotografowane, głowa $\mathrm{w}$ piekarniku itd. A wszystko to bez eksponowania problemu winy i kary, ofiara jest odrażająca, morderca jest efektownym mężczyzną (Sułkowski 2007, s. 24-47).

W tej perspektywie film dzisiejszy jako sztuka komercyjna, albo przynajmniej filmy $z$ obiegu kin komercyjnych, usuwa tzw. ultraviolence z obiegu najpowszechniejszego na margines gatunków niszowych (np. kino gore) i do sal selektywnie uczęszczanych przez amatorów czarnej rozrywki. Komercyjne ujęcia przemocy mają ambiwalentną naturę, z jednej strony są przynętą rzucaną pewnemu segmentowi publiczności (młodzi mężczyźni), a jednocześnie czynią one selekcję wśród innych audytoriów (kobiety, ludzie starsi). Dzisiejszy filmowy gwałt jest cynicznie wyspekulowany przez artystę i producenta.

Poetykę mafijnych egzekucji możemy studiować na przykładzie filmu Gomorra, dzieła autorstwa Matteo Garrone. W przeciwieństwie do dawnych amerykańskich produkcji kina gangsterskiego nie mamy tu do czynienia z przeglądem wyrafinowanych ataków cielesnych i dziwacznych śmierci, w tym filmie nie ma obrazów przewlekłej tortury na miarę Kasyna. Pokazane w Gomorze cztery sekwencje śmierci za każdym razem pointują jakiś socjologiczny wykład 
o mechanizmach i interesach wciągających zwykłych ludzi w śmiertelną machinę mafii. Gomorra nie zaczyna się tytułem, zaczyna się dynamiczną sceną egzekucji. Dwu osobników rozstrzeliwuje w pośpiechu z broni krótkiej jakichś mężczyzn roznegliżowanych, biorących prysznic (Psychoza?). Kino gangsterskie używa zwykle realistycznej fotografii, tu też atakuje oczy widza turpistyczny bałagan, ikonografia bogata jest $\mathrm{w}$ detale i szczegóły, odrapane wnętrza i ulice jak z cinéma vérité. Biorący prysznic mężczyźni otrzymują z najbliższej odległości kilka postrzałów w pierś i w głowę, w gwałtownych, krótkich najazdach kamery. Późniejsze, nieco dłuższe ujęcia kontemplują odrażający widok ofiar, obficie krwawiące obwisłe cielska, wielkie tułowie $\mathrm{w}$ wymyślnych pozach, rozrzucone w łazience i gabinecie. W kolejnej egzekucji kilkuletni chłopiec doświadcza inicjacji w świecie zbrodni, wywabia na ulicę swą troskliwą opiekunkę, kobietę ukrywającą się w domu przed mafią. Zza otwartych drzwi wyłania się mężczyzna i zabija kobietę strzałem w głowę z odległości kilku centymetrów. Krwawiącego trupa ogląda tłum gapiów i sąsiadów. Trzecia egzekucja ma bardziej rozwiniętą ekspozycję. W pokoju liczą pieniądze dwaj mężczyźni, to kasjer mafii oraz jego płatnik. Zwykła scena z życia gomorry. Niespodziewani kilerzy kilkakroć rozstrzeliwują kasjera, siła strzałów rzuca ofiarę z krzesła na ścianę. Bryzgająca krew plami ścianę i biały garnitur siedzącego obok płatnika, tego który przeżył. Ale strzelanina zapewne musiała zacząć się wcześniej, bo przed domem leżą rozrzucone trupy członków obstawy, egzekutorzy wycofując się po akcji omijają je i depczą. Wszystkie trzy egzekucje trwają zaledwie kilka sekund, strzały z broni krótkiej, przeważnie w głowę, są zawsze celne, nie pozostawia się rannych, nikt nie ucieka, są tylko trupy, młodzi, sprawni kilerzy odchodzą nie pokazując emocji. Podziurawione ciała zawsze krwawią obficie, wielka uwaga, jaką operator poświęca plamom czerwonej farby, łączy Gomorrę z kinem Quentina Tarantino, który niegdyś utyskiwał, że w filmach kolegów farba ma tak nienaturalną barwę. Film zamyka czwarta, najdłuższa sekwencja egzekucji. Dwaj kilkunastoletni chłopcy zwabieni w pułapkę na peryferiach miasta, $\mathrm{w}$ opustoszałych szopach i stajniach, zostają zaatakowani $z$ wielu stron. Tym razem zabójcy z broni długiej strzelają do chłopców jak do ruchomych tarcz, z dachów, zza węgieł, zbliżają się, cały czas masakrując ciała. Znowu najdłuższym ujęciem jest kontemplowanie pokurczonych zwłok w kałuży krwi, tym razem kałuża krwi jest największa. Wreszcie zabójcy za kończyny wrzucają dwa ciała do łyżki koparki budowlanej.

W tym filmie gangsterskim nie ma ikonografii tortury, nie eksperymentuje się tu z pornografią śmierci. W zamian jest kilka powtarzalnych obrazów profesjonalnych egzekucji. Jak w każdym kinie gangsterskim, tak i tu odrażająca ikonografia usprawiedliwiana jest wciąż tą samą prostą ikonologią. Obnażenie zbrodni, skompromitowanie płaskich motywacji zabójców, wołanie o opór i organizację społeczną, przestroga dla młodych. Ten film pokazując, jak zorganizowana zbrodnia jest nęcąca i niebezpieczna dla dorastających mężczyzn, jednocześnie gromadzi w salach kinowych takich mężczyzn, miłośników „sil- 
nego" kina, zapewne lekceważących sobie socjologizujące przesłanie. Realistyczna ikonografia kina gwałtu w praktyce odbiorczej daremnie przesłania się prospołeczną ikonologią.

Innym przykładem nowszego komercyjnego kina z bronią palną i bombami domowego wyrobu jest Baader-Meinhof, film rekonstruujący terror Czerwonych Brygad. Zaczyna się od obrazów demonstracji ulicznych, starć z policją i krwawych bijatyk fotografowanych w zbliżeniach z ruchomej, chybotliwej kamery. Przebitkami są obrazy wietnamskiej wojny i ofiar napalmu. Rewolucjoniści zrazu bezkrwawo napadają na banki, potem obserwujemy mordy w ataku na koszary wojskowe, tu przejmujący jest obraz konającego żołnierza. Następnie młodzi rewolucjoniści dokonują egzekucji na wysokich przedstawicielach prawa i establishmentu, strzelając bądź pośpiesznie wysadzając ich $\mathrm{w}$ powietrze, zawsze oglądamy wówczas twarze pełne paniki na chwilę przed śmiercią. Jak wspomniano, tabu niespoglądania w twarz konającego kino zlikwidowało już w drugiej połowie minionego wieku. Sami egzekutorzy giną w końcu w niejasnych okolicznościach. W owej fabularyzowanej rekonstrukcji zideologizowanej zbrodni brak jest wyraźniejszego przesłania. W skrajnym przypadku możliwa jest nawet identyfikacja $z$ buntownikami. Młodzi zbrodniarze zachowują się histerycznie i bohatersko, przy czym $\mathrm{w}$ istocie nie poznajemy bliżej ani ich motywacji, ani ich życiowej historii, nie poznajemy ich środowiska, zakotwiczenia społecznego czy rodzinnego. Jest tylko to, co krytycy nazwaliby cechą kina postmodernistycznego - chaos scen gwałtownych. W tej rekonstrukcji, uchylającej się od interpretacji, każda akcja jest inaczej fotografowana, różnorodnego gwałtu jest tu tak wiele, że nie zdecydowano się na cięcia, film trwa więcej niż dwie godziny. Widzimy, że w dzisiejszym kinie komercyjnym, inaczej niż w fotografii artystycznej, przemoc jest mało spontaniczna, jest estetyzowana i często pokazywana dla niej samej. Fotografia artystyczna pokazywana jest w małych galeriach i w internecie dla tych, którzy jej tam szukają. Kino przemocy i zbrodni natomiast jest wyświetlane w nowoczesnych multikinach, producenci mają też nadzieję, że obrazy takie po kilkutygodniowej sprzedaży w tych kinach trafią na ekrany rodzinnych telewizorów i domowych komputerów.

Przyczyny historyczne spowodowały, że w polskim kinie tematy społecznie ważne pojawiają się z ponadpółwiekowym opóźnieniem. Zbrodnie przeciw narodowi polskiemu w ostatnich latach pokazali Andrzej Wajda i Ryszard Bugajski. Nie można było zrobić filmu o Katyniu bez szczegółowej ilustracji wyrafinowanych technik zabijania oficerów, tak jak nie można było zrobić filmu o powojennym terrorze i kazamatach UB bez sekwencji tortur. Podobnie Mel Gibson nie mógł zrobić Pasji bez wielominutowej golgoty i tortury krzyża. Ikonografia tortury i śmierci ma wstrząsać i wymuszać na widzu refleksję w kwestii winy i kary. Wstrząsające okrucieństwo takich filmów jest artystycznym i percepcyjnym ryzykiem, nie zaś - jak w przypadkach kina komercyjnego - przynętą opatrzoną prospołecznym pretekstem. Ale nawet wówczas wizualne okrucieństwo może likwidować u widza postawę interpretującą, gdyż tym 
razem z przyczyn zupełnie odmiennych niż w poprzednich przykładach drastyczna ikonografia obezwładnia świadomość ikonologiczną widza. U wielu odbiorów Katynia ostatnia, kluczowa, długa sekwencja kaźni oficerów wyparła z pamięci wszystko to, co działo się w filmie wcześniej, po wyjściu z kina nie pamięta się opisanych powikłanych losów ludzi i opowiedzianej historii wielkiego kłamstwa, wyobraźnia pozostaję pod presją krwawej jatki w więziennej piwnicy lub nad dołami w niewielkim lasku. W pamięci wielu widzów Generała Nila natrętnie wraca, wciąż perseweruje kilkusekundowa zaledwie sekwencja tortury ze zrywaniem paznokci, żelazna obroża na dłoni, obcęgi, oprawca siedzący na ofierze, drugi operujący obcęgami, wrzask. Gatunek obu filmów i ich intencja artystyczna jak gdyby usprawiedliwionego rażenia wrażliwości widza, żąda jakiejś zupełnie osobnej analizy, refleksji psychospołecznej tyczącej sytuacji odbiorcy tego rodzaju przedsięwzięć ideowo-artystycznych. Nie ma w tej kwestii badań prowadzących do wyników całkowicie pewnych, każdy widz jest tu własnym laboratorium.

\section{MOBBING, SPOJRZENIE OPRAWCY I IKONOLOGIA NADBUDOWANA WTÓRNIE}

Marshall McLuhan (2001, s. 154) stwierdził, iż „fotografia jest jednym z największych motorów napędowych upiększania się kobiet i mężczyzn w społeczeństwach o odpowiednim standardzie życiowym". Tę manipulacyjną funkcję przejęła głównie fotografia reklamowa. Narzuca ona standardy tego, co jest i co nie jest warte pożądania. W systemie narzucania fałszywych potrzeb fotografia reklamowa odgrywa kluczową rolę i w ten sposób staje się narzędziem przemocy stosowanej w skali globalnej. Nie trzeba odwoływać się do teorii feministycznych, aby zauważyć, jak dalece zmanipulowany wizerunek kobiety wykreowała reklama i jak daleko posunięto się w jej uprzedmiotowieniu. Dzisiejsza reklama w pewnym sensie wciąż jest przejawem dominacji „męskiego spojrzenia". W odniesieniu do tradycyjnego malarskiego aktu pisał o tym zjawisku John Berger (1997, s. 63): „W wypadku europejskiego aktu jako gatunku artystycznego artyści i widzowie-właściciele byli zazwyczaj mężczyznami, natomiast osoby traktowane jako obiekty to zazwyczaj kobiety. Te zachwiane proporcje są tak głęboko osadzone w naszej kulturze, że ciągle jeszcze kształtują świadomość wielu kobiet, które zachowują się wobec siebie w taki sposób, w jaki odnoszą się do nich mężczyźni. Tak jak mężczyźni, poddają one badawczej obserwacji swą kobiecość". Wizerunek kobiety na przedstawieniach reklamowych został poddany fragmentaryzacji. Ciało w reklamie nieustannie podlega procesowi symbolicznego kanibalizmu. Nie tylko jest to nakłanianie do konsumowania wszelkiego typu produktów i usług, obiektem wizualnego kanibalizmu staje się samo ciało kobiety. „Na przykład kobiety przeglądające prasę dla kobiet i oglądające zamieszczone w niej reklamy mają wierzyć, że dzięki tej konsumpcji staną się tak piękne, jak kobiety na fotografiach" (Kowalczyk 2005, s. 64). Tak wykreowany obraz jest nie tylko wyrazem tego, czego pragnie „mę- 
skie oko", ale i tego, czego pragnąć ma kobieta. Mamy tu do czynienia z głęboko zakorzenionym kulturowym programem dominacji, przemocy nie tylko wizualnej i symbolicznej, ale także w konsekwencji realnie doświadczanej opresji.

Fotografia amatorska może zostać wykorzystana przez jej użytkowników na wiele sposobów. Tradycyjny i powszechnie znanym formom, takim tak fotografia rodzinna, turystyczna, okazjonalno-ceremonialna, coraz częściej towarzyszą nowe prywatne formy korzystania z medium. Wielokrotnie skutki takich zastosowań fotografii (oraz krótkich sekwencji wideo) mają znamiona przemocy wizualnej. Powszechność telefonów komórkowych wyposażonych w aparaty cyfrowe umożliwia fotografowanie niemal wszystkiego i wszędzie. Bardzo często zostaje pogwałcona zasada poszanowania prywatności i ochrony wizerunku. Słusznie zauważa Rafał Drozdowski (2006, s. 83), że zintegrowany aparat telefoniczno-fotograficzny wprowadza w sferę społecznych interakcji nieuniknione napięcie i niepewność. Jakże często mamy do czynienia z kradzieżą obrazów, które mogą zostać wykorzystane do tego, aby poniżyć, zawstydzić, zmartwić. Inwigilacja osiągnęła nową formę i skalę. Coraz częściej fotografie takie zostają upowszechnionie w internecie, co ma fatalne konsekwencje. Dochodzi wówczas do czegoś, co możemy określić jako fotomobbing, czyli celowe i systematyczne naruszanie godności osobistej danej osoby ${ }^{3}$. Innym rodzajem fotomobbingu jest robienie zdjęć ukradkiem, będące przejawem wszechobecnego voyeryzmu i skopofilli, czyli przyjemności z podglądania oraz fetyszystycznego przekształcania człowieka w obiekt. Ofiarami tego typu działań często stają się młode kobiety, niejawnie fotografowane (zazwyczaj przez młodych mężczyzn), niejednokrotnie $z$ intencją zamiany ich uchwyconego wizerunku $\mathrm{w}$ obraz-fetysz. Proces fetyszyzowania jednostki ludzkiej jest przejawem seksualnej przemocy, która może dokonywać się za sprawą fotografii. Zdjęcia, zdaniem Christiana Metza (2006, s. 246), dzięki swoim niewielkim rozmiarom, nieruchomości, łatwości ich wykonania często zyskują status fetyszu. Fotografie mogą stać się narzędziem przemocy także wtedy, gdy pierwotne intencje ich wykonania były całkowicie inne. Poniżej przytaczam informację zamieszczoną na internetowym portalu.

„Łomżyńska policja prowadzi postępowanie w sprawie zdjęć nagiej 17-latki, które nielegalnie trafiły do Internetu. Jak napisała "Gazeta Współczesna», zdjęcia dziewczyny znalazły się w sieci po tym, jak zerwała ona ze swoim chłopakiem. Upublicznienie fotografii miało być sposobem na zemstę. Według doniesień gazety, 17-latek nie mógł pogodzić się z tym, że jego dziewczyna go zostawiła i postanowił się zemścić. Wiedział, że robiła sobie nagie zdjęcia. Udało mu się

\footnotetext{
${ }^{3}$ Paweł Szarek przywołuje inne pokrewne pojęcie używane w odniesieniu do internetowych serwisów typu YouTube - cyber-bulling (cyber-nękanie). Powszechnie dostępny i niezwykle popularny serwis pozwalający każdemu użytkownikowi internetu na zamieszczanie krótkich filmów umożliwia stygmatyzowanie na masową skalę. Wiele z tych filmów zostało nagranych za pomocą aparatów komórkowych i bezpośrednio przesłanych do serwisu, zanim ktokolwiek zdążył zareagować, taki film zobaczyło i rozesłało dalej tysiące internautów (zob. Szarek 2008, s. 78-79).
} 
je zdobyć i rozpowszechnić wśród kolegów, którzy zaczęli umieszczać zdjęcia w Internecie. Dla 17-latki był to prawdziwy wstrząs. Jak informuje Wirtualną Polskę podkom. Sławomir Dąbrowski z łomżyńskiej policji, doniesienie na popełnienie przestępstwa złożyli w imieniu niepełnoletniej dziewczyny jej rodzice. Policja ustala, czy zdjęcia będzie można zakwalifikować jako publikację treści pornograficznych. Jeśli tak, sprawcy grozi kara grzywny, ograniczenia wolności lub nawet rok więzienia" 4 .

Dodajmy jeszcze komentarz prokuratora zajmującego się inną sprawą, w której kluczową rolę odegrała przemoc wizualna i umieszczenie zdjęć ofiary w sieci. Tym razem kobieta została napadnięta i sfotografowana przez swoich oprawców w czasie seksualnego napastowania ${ }^{5}$.

„Jeszcze kilka lat temu spraw, w których przestępcy jako «straszakiem" posługują się zdjęciem zrobionym telefonem komórkowym, czy szantażują opublikowaniem kompromitujących zdjęć w sieci, w ogóle nie było. Teraz, niestety, zdarzają się coraz częściej — mówi prokurator Sławomir Mielniczuk, rzecznik prasowy Prokuratury Okręgowej w Kielcach" 6 .

Przemoc wizualna nabiera współcześnie nowego charakteru i każdy może stać się jej ofiarą. Sprzężenie komórkowych aparatów oraz internetu stworzyło nową jakość w sferze komunikacji wizualnej. Swego rodzaju przełomem była wielokrotnie emitowana $\mathrm{w}$ telewizji, nagrana telefonem komórkowym, sekwencja znęcania się toruńskich uczniów nad nauczycielem angielskiego ${ }^{7}$. Autor analizy tego zdarzenia postawił takie oto pytanie: „Dlaczego uczniowie z Torunia zarejestrowali całe zajście, a potem sami rozpowszechniali to nagranie?" (Kasprzak 2006, s. 102). W odpowiedzi podał dwie przyczyny: po pierwsze, filmowanie stanowiło kolejny akt przemocy, miało upokorzyć ofiarę i zademonstrować siłę oprawców, po drugie, nagranie mogło powstrzymać ofiarę przed ujawnieniem zajścia w obawie przed upublicznieniem sprawy. Jak się dowiadujemy, dla uczniów nagrywanie stanowiło po prostu dobrą zabawę.

Ceną doskonalenia technologii różnego typu urządzeń rejestrujących jest wzrost przemocy wizualnej, utrata kontroli nad cyrkulacją prywatnych obrazów (np. wstawienie przez osoby trzecie zdjęć na portalu „Nasza klasa”), oddolna inwigilacja i wreszcie wspomniane przez cytowanego wyżej prokura-

4 http://wiadomosci.wp.pl/kat,1342,title,Zemsta-17-latka-nagie-zdjecia-dziewczyny-w-sieci, wid,10907162,wiadomosc.html [04.03.2009].

5 Takie zdjęcia konfrontują nas ze złem w dwójnasób. Na pierwszym poziomie, ikonicznym — ukazując przemoc, na drugim, wynikającym z okoliczności ich powstania - konfrontując nas $z$ intencją rozkoszowania się tym złem ponownie. Złe obrazy to takie, które powstają nie po to, aby zło napiętnować, ale po to, aby się nim napawać. Dla tych, którzy je robią, pełnią funkcję pamiątki, trofeum bądź fetyszu.

6 http://www.echodnia.eu/apps/pbcs.dll/article?AID=/20090327/POWIAT0113/319973273 [01.04.2009].

${ }^{7}$ Zajście miało miejsce w Toruniu, w dniu 19 czerwca 2003 r. i wywołało publiczną debatę nad bezpieczeństwem $\mathrm{w}$ polskich szkołach. 
tora niebezpieczeństwo zastraszania czy szantażowania ${ }^{8}$. Na liście dyskusyjnej Dontdatehimgirl.com porzucone kobiety dają upust swoim emocjom, opisując zachowania byłych partnerów. Znajduje się tam nawet zdjęcie ohydnego narzeczonego, który zgwałcił analnie.

W podanych przykładach fotografujący naruszali godność osobistą osób trzecich, wykonując zdjęcia ośmieszające, upokarzające lub uprzedmiotawiające swoje ofiary. W pewnych sytuacjach jednak obraz fotograficzny stał się narzędziem przemocy, choć jego powstaniu towarzyszyły odmienne intencje. Wielokrotnie omawiany już przypadek amerykańskich żołnierzy z Abu Gharib jest dramatyczną i dosadną egzemplifikacją imperatywu fotografowania wszystkiego. Historia strażników znęcających się nad irackimi więźniami stała się głośna, gdy upubliczniono fotografie ukazujące okrutny proceder. Zdjęcia, co najważniejsze, wykonali sami oprawcy. Zanim te fotografie obiegły cały świat, zupełnie bezproblemowo funkcjonowały jako wygaszacze na komputerach pracowników więziennej administracji. Zwycięzcy zawsze fotografują pokonanych, zdjęcie staje się dowodem triumfu, dobrze wykonanego zadania, nowoczesnym skalpem. Prześladowanie połączone $z$ fotograficznym rejestrowaniem upowszechniło się w czasie drugiej wojny światowej, głównie za sprawą niemieckich żołnierzy. Niemcy pozostawili po sobie ogromną liczbę zdjęć, na których utrwalali swoje zbrodnie. Uwieczniali jeńców pędzonych na egzekucje, sceny kaźni, życie w łódzkim czy warszawskim getcie, przesiedlenia - fotografowali z pasją wojenny koszmar. Ich małe i dobre aparaty fotograficzne stanowiły doskonałe dopełnienie ekwipunku żołnierza-zdobywcy. Fotografowanie egzekucji stało się tak powszechne, że 22 lipca 1941 r. dowódca sztabu armii „Środek”, generał Otto Wöhler, wydał rozkaz zabraniający żołnierzom wykonywania i rozpowszechniania tego typu fotografii (Struk 2007, s. 103). Kolekcjonowanie fotograficznych pamiątek wojennych staje się przywilejem wygranych, jednak okazuje się, że zdjęcia takie mogę obrócić się przeciw swoim autorom. Dokumentacja wojennego triumfu staje się wtedy dowodem zbrodni. Charakter pamiątkowej fotografii wojennej wynika z przemocy, która jest sednem wszelkich działań militarnych. Relacja ofiara-kat jest tu oczywista, władzę ma ten, kto dysponuje większą siłą. Aparat fotograficzny staje się takim samym narzędziem dominacji jak karabin.

Odwróceniem tej sytuacji są próby dokumentowania przemocy przez jej ofiary. Jednym z najdramatyczniejszych przykładów udanej próby „wyrwania obrazów z piekła" była dogłębnie analizowana przez Georgesa Didi-Hubermana heroiczna akacja wykonania zdjęć na terenie obozu koncentracyjnego Auschwitz przez członków grupy Sonderkommando. Więźniowie ci zajmowali

8 O skutkach rozpowszechnienia się miniaturowych aparatów cyfrowych i ich inwazji na prywatne życie pisał Krzysztof Olechnicki (2005, s. 49). Zauważył, że stały się one potencjalnym narzędziem przemocy symbolicznej, co objawia się między innymi utowarowieniem i wirtualizacją ciał anonimowych mężczyzn i kobiet. 
się $\mathrm{w}$ obozach śmierci przygotowaniem i prowadzeniem infrastruktury masowego unicestwiania. Pracowali przy obsłudze pieców krematoryjnych, przy tak zwanych dołach spaleniskowych, "porządkowali” to, co pozostawało ze spalonych ciał. „Pewnego dnia, latem 1944 r., członkowie Sonderkommando odczuli nieodpartą potrzebę, jakże dla nich niebezpieczną, wyrwania z piekła swojej pracy kilku fotografii mogących dać świadectwo horroru i rozmiaru dokonującej się masakry" (Didi-Huberman 2008, s. 14). W wyniku akcji wykonano cztery fotografie ukazujące prace grupy przy dołach spaleniskowych oraz kobiety pędzone do komory gazowej krematorium V. Te obrazy nie miały prawa powstać, a jednak mimo wszystko cztery strzępy prawdy o Auschwitz, prawdy o planie zniszczenia totalnego „żydowskich narodów Europy” — jak podkreśla autor - zostały wyrwane.

\section{DOKUMENTACJE KORESPONDENTA WOJENNEGO}

Wydaje się, że problem agresji i przemocy najczęściej podnoszony jest w odniesieniu do fotografii reporterskiej. Prace reporterów często stanowią świadectwo drastycznych zbrodni popełnianych w różnych częściach świata, dyskusje medialne koncentrują się jednak nie na obrazie, ale na tym, czy fotograf miał moralne prawo wykonać dane zdjęcie ${ }^{9}$. „Opinia publiczna zwraca się przeciwko nim jako dostarczycielom złych informacji; obrazów wojny, okrucieństwa, śmierci. Jednocześnie oskarża się ich o to, że nie próbują interweniować, ratować rannych i nieść pomocy" (Kułakowska 2009, s. 55). Należy dodać, $\dot{z}$ e opinia publiczna, w tym sami oskarżyciele, laknie tego typu fotografii ${ }^{10}$. Nie ulega wątpliwości, że analizując przemoc w odniesieniu do sztuki fotoreportażu, należy również rozgraniczyć sam akt fotografowania, który może nosić znamiona przemocy, oraz tę przemoc, która została utrwalona na obrazie. Fotoreporter wyruszający w miejsca katastrof czy wojennych konfliktów pamięta o konkretnych rynkowych oczekiwaniach oraz o zasadach rządzących tego typu fotografią. „Odbiorcy narzucają te zasady fotoreporterowi, chcą zobaczyć coś, czego nie byli świadkami. Po przyjrzeniu się fotografii wiedzą, że mają dzięki niej wyobrażenie wizualne o prezentowanej tragicznej historii. Fotoreporterzy, odpowiadając na zapotrzebowanie czytelników, pokazują czyjś ból

${ }^{9}$ Możliwe, że łatwiej jest karcić fotografa, niż otwarcie przyznać, że jesteśmy w stanie doskonale funkcjonować z obrazami przemocy, która nas nie dotyczy. Zwrócił na to uwagę, brytyjski reporter Tim Hetherington mówiąc: „Zastanawiam się dlaczego, tak wielu ludzi troszczy się o moje morale, o bagaż emocjonalny, który to ja muszę nosić, a nie ci ludzie. Ja mogę z tym żyć” (fragment wywiadu O krok dalej niż blisko, przeprowadzonego przez Weronikę Mliczewską, „Gazeta Wyborcza”, 3-4 stycznia 2009, s. 10).

10 Corocznym festynem udokumentowanego okrucieństwa jest pokonkursowa wystawa World Press Photo. „[...] to wystawa, która cieszy się ogromną popularnością, gdzie tłumy ludzi przychodzą m.in. po to, by popatrzeć na martwe ciała. Śmierć jest tu sprowadzona do roli widowiska, ale też wystawiona na sprzedaż" (Kowalczyk 2006, s. 27). 
z bliskiej perspektywy, ponieważ są przekonani, że takimi ujęciami wzmaga się zainteresowanie" (Wolny-Zmorzyński 2006, s. 123). To bliskie spojrzenie nie tylko wzmaga zainteresowanie odbiorcy, ale i poświadcza autentyczność zdjęcia. Wielu reporterów odrzuca teleobiektywy, zdając sobie sprawę, że jedynie bliskość umożliwi im autentyczne „dotknięcie” tematu. Wypowiedź jednego z czołowych polskich fotoreporterów, Krzysztofa Millera, potwierdza rynkową istotność krótkoogniskowych obiektywów:

„Przeanalizowałem poprzednie zdjęcia. Okazało się, że z teleobiektywu prawie żadne się nie sprzedawały. W związku z tym po co zabierać ciężkie obiektywy? Łatwiej jest uciekać $z$ małą torbą niż z dużą. [...] zdjęcia muszą śmi er d zi eć. Dlatego moja rada: nigdy nie pytaj, czy możesz kogoś fotografować. Jak ci nie pozwoli, to już nie masz wyjścia, nie możesz zrobić zdjęcia. Najpierw robisz, a potem pytasz"11.

Drugi cytowany fragment jest odpowiedzią na pytanie dotyczące ochrony wizerunku:

„W Afganistanie go nie znają. Zresztą Gazeta ma dobrych adwokatów, jak widać po sprawie Rywina (śmiech). Poza tym mnie to nie interesuje, niech fotoedytor się męczy" 12 .

Zasady, które muszą być przestrzegane w krajach europejskich, nie obowiązują w Afryce czy w niektórych państwach azjatyckich. Tam nikt nie będzie ścigał fotoreportera za nadużycia $\mathrm{w}$ zakresie ochrony wizerunku. Zadaniem reportera jest dostarczenie dobrych (atrakcyjnych) zdjęć, przemoc wizualna zostaje uzasadniona celem pracy. Przemoc fotografii może przybrać także inne formy, wtedy gdy obecność reportera wpływa w jakimś stopniu na gwałtowność wydarzeń. Z takim zarzutem spotkał się Ross Baughman, który w 1978 r. wykonał kontrowersyjny reportaż w ogarniętej wojną domową Rodezji. Problem polegał na tym, że reporter podczas pracy był ubrany w wojskowy mundur i nosił broń, tak jak inni oprawcy mieszkańców napadniętej wioski. Uznano, że jego uczestnictwo w akcji mogło zwielokrotnić gorliwość pacyfikujących wioskę żołnierzy. Pojawianie się fotoreportera może wyzwolić agresywne postawy. W pewnych sytuacjach ta agresja może zostać zwrócona przeciw niemu samemu. Doświadczył tego brytyjski fotograf Don McCullin. „Wstrząsnęła nim [...] reakcja pewnej kobiety w Bejrucie, która oszalała z rozpaczy, kiedy bomba zabiła wszystkich członków jej rodziny. Zaatakowała ona McCullina, gdy chciał zrobić jej zdjęcie nie pytając jej o zgodę (co było wbrew jego własnym zasadom)" (Roberts 1993, s. 6).

Drugi aspekt przemocy fotoreportażu dotyczy samych zdjęć. Przemoc utrwalona na fotografiach, świadectwa okrucieństw, cierpienia i śmierci stały

\footnotetext{
11 http://www.reporter.edu.pl/fotoreportaz/warsztat/zdjecie_musi_smierdziec_rozmowa_z_ krzysztofem_millerem [03.04.2009].

12 Tamże.
} 
się elementem ikonosfery współczesnego człowieka. Przemoc dokumentowana przez fotoreporterów tym różni się od przemocy zawartej w obrazie artystycznym, że nie jest kreowana. Rany, ból i cierpienie są realne. Dlatego reportaż znika z łamów gazet i ilustrowanych magazynów, jak mówi reporter James Nachtwey: „to są materiały niewygodne dla społeczeństwa. Ludzie bardziej są dziś skupieni na rozrywce, modzie, gwiazdach. Reklamodawcy nie chcą pokazywać swoich produktów obok obrazów tragedii, nie chcą by ich marki były kojarzone z cierpieniem i tragedią" (cyt. za: Łyżwa 2006, s. 109).

Wszystko, czego świat zachodni dowiaduje się o wojnach w innych rejonach, płynie poprzez gazetowy reportaż, telewizję i internet. Często stawia się pytanie o realne skutki pokazywania ludziom Zachodu zapośredniczonego medialnie cierpienia Innych. Na podobne pytania udzielane są sprzeczne odpowiedzi. Albo zagęszczenie codziennych medialnych obrazów wojen, rewolucji i krwawych buntów wywołuje znużenie i niechętne ofiarom psychiczne mechanizmy obronne, albo - co niesie nadzieję — podobne wiadomości i obrazy rozszerzają obszary społecznej wrażliwości i współczucia wobec odległych Innych. Albo media włączają widza w odległą rzeczywistość, aktywizują go, ułatwiając kontakt z cierpiącymi Innymi, albo przeciwnie - widzowie żywią nieufność wobec rozwiniętych, przesadnie wyspecjalizowanych technologii komunikacyjnych (montaż, powtórki, krążenie tych samych sekwencji, przyśpieszenia, nałożenie ścieżki dźwiękowej na obraz itd.), widzowie mają rosnące poczucie ułudy tej sztucznej bliskości z Innymi (Chouliaraki 2007, s. 306, 310). Wobec wyraźnej sprzeczności „albo-albo” między pesymistyczną dystopią a optymistyczną utopią $\mathrm{w}$ kwestii etycznej roli mediów warto sprowadzić teoretyczny problem do konkretnych analiz przebiegów komunikacyjnych w telewizji i w internecie. Postawmy tezę roboczą, że media elektroniczne odwołują się do reportażu wojennego w sposób celowy, operując obrazem rozważnie i w sposób oparty na edytorskim doświadczeniu, słowem - wojna w telewizji przeznaczona dla zachodniego widza siedzącego wieczorem na kanapie (tzw. swojskość odbioru), taka wojna podlega medialnej higienizacji. Czy relacja $z$ wojny powinna podlegać higienizacji w interesie zdrowia psychicznego widza? Ta sama wojna $w$ internecie, nawet $w$ tej samej stacji nadawczej, pełna jest obrazów drastycznych, trudnych do zniesienia, nakierowanych na widza aktywnie poszukującego dokumentacji.

Sobota, 17 stycznia 2009 r., 21 dzień zbrojnej interwencji Izraela w Strefie Gazy. Wprowadzono do strefy czołgi, trwają bombardowania wybranych celów w strefie, trwa ostrzał czołgowy, w miastach żołnierze izraelscy prowadzą walki z bojownikami Hamasu. Siły zbrojne Hamasu codziennie wystrzeliwują kilkadziesiąt rakiet na przygraniczne osiedla. Nikt nie wiedział, że to był ostatni dzień walk przed nie podpisanym między stronami, ale faktycznym zawieszeniem broni. Nie zajmiemy się całą retoryką reportażu wojennego w mediach zachodnich ani medialną walką propagandową między stronami konfliktu. Skupimy się na sposobie fotografowania i filmowania wojny we współczesnych 
zachodnich mediach. Co fotografuje BBC Word? To dzień po zbombardowaniu budynku szkoły w Rafah. Przez cały dzień na ekranie pojawia się dymiąca ruina budynku oglądanego przez rzadkich gapiów i przechodniów. Następnym informacjom towarzyszy, ten sam od kilku dni, obraz świetlistych wybuchów w zaciemnionym palestyńskim mieście. Na poziomie ikonografii rozbłyskujące rakiety filmowane $z$ dużej odległości na ciemnym tle tworzą widowiskowy spektakl. Jest też czołg fotografowany z dużej odległości, stoi na łące przez cały dzień. Długie, odległe ujęcia mniej angażują emocjonalnie, nie rodzą w widzu natychmiastowej empatii, w każdym razie działają inaczej niż gwałtowne zbliżenia i krótkie migawki. Potem telewizja satelitarna pokazuje na przemian bądź reportera, bądź reporterkę, komentujących „bombardowanie trwa, nikt nie jest bezpieczny", choć w dziennym tle krajobrazu palestyńskiego miasta fotografowanego $z$ odległości kilku kilometrów nikt nie wydaje się zagrożony. Trzecie zdjęcie, powracające tego dnia, a znane już wcześniej, pokazuje rannego młodego człowieka niesionego do samochodu osobowego. Ostatnie ujęcie towarzyszące informacjom to widok kobiet i dzieci bez uśmiechu siedzących pod murem. W istocie na poziomie ikonografii mamy do czynienia raczej $z$ fotografią obyczajową niż z reportażem wojennym. Nie ma ulicznych walk, raz tylko przed dwoma dniami uchwycono dymy z wysadzonego budynku, w którym kryło się wejście do przemytniczego tunelu hamasowców. Następnego dnia obok zbombardowanej szkoły pojawiły się ruiny zbombardowanego szpitala. Trupy zapewne uprzątnięto już wcześniej, zabici są tylko w informacji werbalnej, ich liczba wciąż rośnie. Natomiast widoku ostrzeliwanego Izraela tego dnia nie było wcale.

Czy działa tu cenzura wojskowa, czy polityczna, czy na poziomie ikonografii mamy do czynienia z językiem ezopowym? Czy zabrakło fotoreporterów i zdjęć po kilkudziesięciu dniach walki? Oczywiście telewizja BBC, tak jak każda inna telewizja, organizując informację rządzi się rutynową regularnością - wiadomości są powtarzane w krótkich, zrównoważonych sekwencjach, niezależnie od ich wagi czy ludzkiego wymiaru, dla jednych ważna jest informacja o wojnie, dla innych ważniejsza jest wypłacalność Citibanku. Migawkowy montaż wiadomości telewizyjnych, pośpieszny ciąg odmiennych sekwencji, chaos obrazów gwałtownych, likwidują skupioną spostrzegawczość widza i jego refleksyjność, nie jest on nawet pewny, czy ogląda jeszcze wojnę w Gazie, czy już demonstracje i bójki studentów z policją w Atenach, słowo komentarza nie nadąża za obrazem, natłok obrazów, z reguły powtarzanych, rzadziej pokazanych po raz pierwszy, pomieszanych wedle nieodgadnionej zasady — wszystko to wzmaga Mannheimowską dedystansację wartości. Nawet informacja o krwawej wojnie w końcu zużywa się medialnie, informacje o ofiarach po kilku dniach nie są newsami. 17 stycznia, 21 dnia wojny, najważniejszym newsem okazało się „morderstwo stulecia” dokonane na francuskiej studentce w Perugii przez jej kolegów. W rutynowej praktyce informacyjnej obraz wojny systematycznie lokuje się tuż przed żartobliwą reklamą, przed sympatycznym panem od sportu 
i przed seksowną panią od pogody. Spostrzeżeniem najważniejszym jest, iż ani $\mathrm{w}$ telewizjach polskich, ani w BBC, ani CNN nie pokazano ofiar, w telewizji były gruzy, ruiny, w ogóle nie było trupów, choć powtarzano informacje o rosnącej liczbie zabitych i rannych. Telewizja jest medium domowym, którego wizualna retoryka, nawet dotycząca wojny, nie może być nazbyt drastyczna. Tezy poznawcze i interpretacje pojawiają się $\mathrm{w}$ infotainmencie tylko $\mathrm{w}$ warstwie werbalnej, $w$ ten sposób zaledwie towarzysząc dominującej przecież percepcji wzrokowej. Telewizyjny infotainment $\mathrm{w}$ doborze ikonografii nieuchronnie oswaja wojnę, na co znajdziemy dowody przez porównanie różnych komunikatorów: telewizji i internetu. Podobna retoryka cechowała wszystkie telewizje polskie, prezentowane $u$ nas fotografie pochodziły zresztą $z$ tego samego źródła.

Trzeba jednak przyznać, że w końcu, ze znacznym opóźnieniem, BBC wyemitowała dramatyczny reportaż wojenny. Było to, gdy pojawiła się nadzieja, a więc w trzy dni po zawieszeniu broni między stronami, w 25 dni po rozpoczęciu izraelskiej interwencji. Film pokazuje chłopca na łóżku szpitalnym, informacja zza ekranu sugeruje, że dziecko nie będzie nigdy już poruszać się na własnych nogach. Ojciec stracił w bombardowaniu żonę i dwoje innych dzieci, teraz od reportera $\mathrm{w}$ wideo robionym na żywo w ruinach domu dowiaduje się o kalectwie syna. Patrzy w kamerę, prosto w oczy widza. Po raz pierwszy od kilku dni mamy do czynienia z techniką wymuszonej na widzu empatii. Ojciec odchodzi w milczeniu, nie ma gestów gniewu, jest przejmująca rozpacz.

Drugie domowe medium, jakim jest internet, na nowo eksperymentuje $z$ retoryką obrazów wojny. W internecie ikonosfera może być interaktywna, za pomocą linków widz wybiera rejon świata do oglądania, a potem konkretne wideo. Spośród innych można wybrać narracje z Bliskiego Wschodu. Okazało się, że każdego dnia gromadzone były w BBC obszerne dokumentacje filmowe. Wspomnianego 17 stycznia pokazano dymiące ruiny szpitala $\mathrm{w}$ al-Quds, $\mathrm{w}$ istocie dwu budynków na terenie szpitala zbombardowanych w trakcie walk. Strażacy dogaszają ruinę. Następne ujęcie pokazuje pacjentów i rannych ewakuowanych nocą ze szpitala na ulicę. Łóżka stoją na trotuarze, lżej ranni stoją między łóżkami. Lekarz otoczony pacjentami i personelem trzyma w rękach i demonstruje pozostałości łuski pocisku czołgowego. Jest zdesperowany, niektórzy ranni byli na oddziale intensywnej terapii, dzieci wcześniaki w inkubatorach. Po drugiej stronie konfliktu kilka innych wideo $z$ tego samego dnia ukazuje rakiety spadające na południowy Izrael. I znowu po tej stronie, pogrzeb jednego $z$ liderów Hamasu, ogólny widok ulic w strefie Gazy po trzytygodniowych bombardowaniach.

Internetowe $\mathrm{CNN}$ tego samego dnia proponuje widzowi kilka własnych filmów z Gazy. Najbardziej dramatyczny jest obraz ze zbombardowanego Rafah. Na stole ranny, w drastycznym zbliżeniu zakrwawiona twarz, uszkodzone, oślepłe oczy, przez poszarpaną odzież widać inne rany na całym ciele. Zespół lekarzy zajmuje się rannym, a przed stołem chirurg Egipcjanin szczegółowo 
i z gniewem wylicza i opisuje urazy rannego. W kolejnym reportażu przewodnikiem, który oprowadza pośród ruin, jest Palestyńczyk. Na opustoszałych ulicach chłopcy grają w piłkę. Dalej pogrzeb, gniewna demonstracja niewielkiej grupy żałobników, zbliżają się do pustynnego, piaszczystego cmentarza — „W tym momencie odbywa się kilka pogrzebów jednocześnie”. W dalszej kolejności tego dnia można było jeszcze obejrzeć migawki pokazujące, jak siły izraelskie przesuwają się w głąb Gazy, jak karetki ratunkowe są blokowane na granicy, jak został zaatakowany obóz uchodźców, nieustanne bombardowanie Gazy i z drugiej strony rakiety nad Izraelem.

Widzimy, iż także domowa telewizja CNN, podobnie jak BCC, wykorzystała zaledwie niewielkie, $z$ reguły statyczne fragmenty aktualnego dorobku swych reportażystów i korespondentów. Natomiast wojna relacjonowana w internecie stała się niszową grą wojenną, z powodu interaktywnej współpracy z widzem, który wybiera między linkami. Internetowym obrazom towarzyszy narracja korespondentów wojennych, ponadto są wypowiedzi uczestników zdarzeń aktorzy żądają od widza natychmiastowego opowiedzenia się po ich stronie. Jest to gra zero-jedynkowa, niewątpliwie okrutna, bo aktualna i nie wahająca się pokazywać ofiary, zabitych i rannych. Ikonografia wojny w internecie oraz zawarte tam komentarze są obszerniejsze, realistyczne i drastyczne w porównaniu $z$ cenzurowanym materiałem telewizyjnym. Internet dostarcza jednak informacji jedynie tym, którzy jej aktywnie poszukują i potrafią to robić.

Jednak nawet wciąganie widza w grę wojenną za sprawą internetu nie musi rozbudzać jego skłonności do refleksji o rzeczywistej przyczynie cierpienia Innych. Także takie wideoinformacje nie pozbywają się bowiem pośpiesznej, chaotycznej i zdawkowej retoryki, nierównie obszerniejsza ikonografia nie wspiera też tutaj głębszej interpretacji. Dzisiejsza elektroniczna ikonosfera nie wymusza na widzu refleksyjnego opracowania, pointowania i wyciągania wniosków. Cyfrowej mozaice towarzyszy zaledwie szczątkowy komentarz redakcyjny wydawcy wiadomości, przywołujący nas do porządku myślenia linearnego, w praktyce obrazy pochłaniają bez reszty percepcyjną potencję odbiorcy, tego obserwatora wojny jakichś odległych Innych. W epoce komunikacji elektronicznej i cyfrowej zawsze brakuje czasu na rozwinięcie tematu, bo ten sam temat trzeba będzie powtórzyć za pół godziny lub najwyżej za godzinę. Nawet kilka dni później w problemowej dyskusji o wojnie na Bliskim Wschodzie wszyscy się śpieszą, gdyż „czas nas goni”, przebitki i migawki filmowe zastępują wszystko to, co niejasne i co nigdy nie zostanie wyartykułowane.

\section{UWAGI KOŃCOWE}

Wartość informacyjna obrazu wielekroć przekracza potencjał informacyjny słowa. Jednakże fenomenologia obrazu ma swą specyfiką, nie w każdej sytuacji odbiorczej aktualizowana jest informacyjna potencja obrazu, obraz pozwala widzowi zatrzymać się na etapie immanentnej kontemplacji, obraz nie wy- 
musza kategorycznie rekonstruowania funkcji referencyjnej. Jean Baudrillard mówi o implozji sensu we współczesnych mediach. Gwałtownie przyrastające obrazy, natłok przedstawień, dramatyzacja relacji, drastyczność dokumentacji - wszystko to nakierowane jest na przekształcanie informacji w spektakl. W rezultacie udramatyzowany infotainment pożera własną treść, pożera sens. Współczesna skrajnie udramatyzowana informacja $\mathrm{w}$ sensacyjnej formule nie wytwarza sensu, lecz wyczerpuje się na inscenizowaniu komunikacji. Dodajmy od siebie, iż to właśnie obrazy nieszczęścia i przemocy są głównym sposobem przekształcania informacji w spektakl, a emocjonalna fascynacja spektaklami gwałtu nie musi wytwarzać sensu. Nadawcy medialni wiedzą, że zagęszczenie drastycznych obrazów odwołuje się do emocjonalnej asymetrii każdego widza, w jego pamięci częściej pozostają obrazy drastyczne niż dokumentacje wartości i wyobrażeń pozytywnych. Media komercjalizują się, prowadzą konkurencyjną grę rynkową, niezależnie od deklarowanej misji informacyjnej. Infotainment, czyli zabawianie dramatycznymi obrazami, karnawalizacja przemocy, łatwo kształtuje model komunikacji pozbawionej odpowiedzi. Baudrillard w swej daleko posuniętej krytyce kultury współczesnej i masowych audytoriów zauważa, że widzowie zgadzają się na taki model komunikacji, w której poprzestaje się na spektaklach nieformułujących istotnych pytań i zatem nieudzielających istotnych odpowiedzi. Masy oglądają udramatyzowane spektakle i nie oczekują niczego więcej, nie oczekują żadnych odpowiedzi. Obrazy przemocy wydają się skutecznym instrumentem kreowania ikonosfery symulakrów, mechanizmem percepcji znaków bez odniesienia, bez interpretacyjnej ikonologii.

W swojej ostatniej książce Regarding the Pain of Others Susan Sontag (2003) wnikliwej analizie poddaje fotografie przedstawiające horror wojny, przemoc i śmierć. Dokonuje między innymi redefinicji swojego słynnego stwierdzenia o znieczulającym działaniu obrazów cierpienia, o tym, że społeczeństwo nasyciło się już takimi fotografiami i tym samym straciły one swoją moc. Zdjęcia takie wciąż mają zdolność szokowania odbiorców, nie mają jednak mocy wyjaśnienia, jaką niosą ze sobą narracje słowne. Współczesny system medialny cynicznie manipuluje obrazami wojny, a wojskowi i decydenci polityczni skutecznie kontrolują możliwość wykonywania przez reporterów zdjęć na linii walk. Jednak tego typu obrazów nie zabraknie, nie pojawi się postulowana przez Sontag trzydzieści lat temu ekologia obrazów. Autorka podkreśla, że okropności nie znikną z naszej ikonosfery, zawsze jednak pozostaną jedynie próbą wyobrażenia tego, co jest niewyobrażalne. Erich Fromm opisując związek kultu techniki z nekrofilią twierdził, że w czasach industrialnych zmalało zainteresowanie człowieka innymi ludźmi, przyrodą czy transcendencja, wzrosło natomiast upodobanie do mechanicznych, nieżywych artefaktów. Fotografia jest jednym z przywołanych przez niego przykładów umiłowania technicznych gadżetów z jednej strony, a nekrofilnego przekształcenia aktu widzenia $w$ przedmiot $z$ drugiej. Fromm, w przeciwieństwie do swego mistrza Freuda, nie przypisuje naturze ludzkiej destrukcyjnego instynktu Tanatosa. Rozważając relacje skłonności bio- 
filnych i skłonności metaforycznie określonych jako nekrofilne twierdzi, iż zaledwie niewielka część osobników ludzkich, mniej niż co piąty, rozwija w sobie te drugie. Upodobanie do agresji, wrogości i destrukcji nie tkwi w naturze ludzkiej, lecz jest wyborem człowieka socjalizowanego w określonych warunkach, poddanego wpływom kultury masowej, dodajmy od siebie — przez lata naświetlanego obrazami gwałtu. W amerykańskiej psychologii społecznej wciąż podkreśla się, wbrew przekonaniu Susan Sontang, niebezpieczeństwo emocjonalnego znieczulenia, percepcyjnego zobojętnienia na cierpienie innych pod wpływem potężniejącego strumienia ikonografii przemocy. Innym pojęciem z pogranicza psychologii społecznej jest adiaforyzacja, oznaczająca taką postawę odbiorczą, kształtowaną przez współczesne media, która pozwala przyglądać się cierpieniu innych bez jakiejkolwiek oceny moralnej. Współczesna ikonosfera pogłębia praktykę machinalnego oglądania przemocy całkowicie poza doświadczeniem etycznym. Naturalna dla człowieka empatia wobec innych oraz pierwotna rama moralnych odniesień zużyły się w procesie długotrwałej ekspozycji obrazów gwałtu. George Gerbner obstawał w tej kwestii przy hipotezie medialnego syndromu świata podłego, wrogiego i niebezpiecznego. Ten klasyk badań nad symboliczną przemocą twierdził, że media szerzą społeczną paranoję, kształtują światopogląd człowieka o wzrastającym wciąż poczuciu zagrożenia, wrogiego innym, nieufnego i w związku $z$ tym podległego manipulującej nim władzy. Do tego trzeba dodać efekt rezonansu psychicznego, kiedy to na realne przykre doświadczenia człowieka nakładają się urazy z poziomu przedstawień wizualnych, pogłębiając traumę i nie pozwalając wyprzeć ze świadomości tego, co boleśnie ciąży (Sułkowski 2007, s. 93-100). Przytoczone tu różne objaśnienia sytuacji współczesnego konsumenta kultury medialnej za każdym razem wskazują jakąś cząstkę prawdy. Koncepcje można by mnożyć, jednak nawet trafne diagnozy nie są tożsame z udzieleniem nam jakiejś pożytecznej porady.

\section{BIBLIOGRAFIA}

Berger John i in., 1997, Sposoby widzenia, tłum. Mariusz Bryl, Rebis, Poznań.

Baudrillard Jean, 2005, Symulakry i symulacja, tłum. Sławomir Królak, Sic!, Warszawa.

Chouliaraki Lilie, 2007, W stronę analityki mediacji, w: Krytyczna analiza dyskursu. Interdyscyplinarne podejście do komunikacji społecznej, Anna Duszak, Norman Fairclough (red.), Universitas, Kraków.

Drozdowski Rafał, 2006, Obraza na obrazy. Strategie społecznego oporu wobec obrazów dominujacych, Wydawnictwo Naukowe UAM, Poznań.

Didi-Huberman Georges, 2008, Obrazy mimo wszystko, tłum. Mai Kubiak Ho Chi, Universitas, Kraków.

Fromm Erich, 1998, Anatomia ludzkiej destrukcyjności, tłum. Jan Karłowski, Rebis, Poznań.

Kasprzak Tomasz, 2006, Kosz na głowie nauczyciela, czyli filmowanie przemocy $w$ szkole, „Societas/Communitas”, nr 2.

Kowalczyk Izabela, 2005, Wobec wizualnego kanibalizmu, w: Przestrzenie fotografii. Antologia tekstów, Tomasz Ferenc, Krzysztof Makowski (red.), Wydawnictwo Galeria f5, Łódź. 
Kowalczyk Izabela, 2006, Ciato zszargane $w$ fotografii dokumentalnej i sztuce wspótczesnej, w: Sesja. Punkt widzenia. Fotografia ciała, Muzeum Historii Fotografii w Krakowie.

Krajewski Marek, 2003, Kultury kultury popularnej, Wydawnictwo Naukowe UAM, Poznań.

Kułakowska Katarzyna, 2009, Zdjęcie jako „dowód rzeczowy”, w: Interpretując fotografię. Śladami Susan Sontag, Kazimierz Kowalewicz, Tomasz Ferenc (red.), Galeria f5 \& Księgarnia Fotograficzna, Kraków.

Łyżwa Beata, 2006, Spojrzeć z bliska, w: Odwaga patrzenia. Eseje o fotografii, Tomasz Ferenc (red.), Fundacja Edukacji Wizualnej, Łódź.

Magala Sławomir, 1982, Fotografia w kulturze wspótczesnej, Centralny Ośrodek Metodyki Upowszechniania Kultury, Warszawa.

McLuhan Marshall, 2001, Wybór tekstów, Eric McLuhan, Frank Zingrone (red.), tłum Ewa Różalska, Jacek M. Stokłosa, Zysk i S-ka, Poznań.

Metz Christian, 2006, Fotografia i fetysz, „Kwartalnik Filmowy”, nr 54-55.

Ogonowska Agnieszka, 2004, Przemoc ikoniczna. Zarys wykładu, Wydawnictwo Naukowe Akademii Pedagogicznej, Kraków.

Olechnicki Krzysztof, 2005, Fotografia dla każdego. Spoteczne funkcjonowanie fotografii $w$ dobie kultury konsumpcyjnej, w: Przestrzenie fotografii. Antologia tekstów, Tomasz Ferenc, Krzysztof Makowski (red.), Wydawnictwo Galeria f5, Łódź.

Olechnicki Krzysztof, 2006, Przemoc fotografii, w: Formy przemocy w kulturze wspótczesnej, Hanna Mamzer (red.), Wydawnictwo Naukowe Uniwersytetu im. Adama Mickiewicza, Poznań.

Olechnicki Krzysztof, 2009, Fotoblogi, pamiętniki z opcja przekazu. Fotografia i fotoblogerzy w kulturze konsumpcyjnej, Wydawnictwa Akademickie i Profesjonalne, Warszawa.

Roberts Pam, 1993, Wojna i pokój, tłum. Jerzy Jarniewicz, katalog wystawy „Don McCullin. Retrospektywa", Muzeum Sztuki, Łódź.

Szarek Pawel, 2008, YouTube - specyfika medium i możliwości jego badania, w: Obrazy $w$ sieci. Socjologia $i$ antropologia ikonosfery Internetu, Tomasz Ferenc, Krzysztof Olechnicki (red.), Wydawnictwo Naukowe UMK, Toruń.

Sontag Susan, 2003, Regarding the Pain of Others, Farrar, Straus and Giroux, New York.

Struk Janina, 2007, Holokaust $w$ fotografiach. Interpretacje dowodów, tłum. Maciej Antosiewicz, Prószyński i S-ka, Kraków.

Sułkowski Bogusław, 2007, Przemoc i pornografia śmierci jako przynęty medialne, Wydawnictwo Uniwersytetu Łódzkiego, Łódź.

Witkin, 1995, Joel Peter Witkin: A Retrospective, Scalo, New York-Milano.

Witkowska Sylwia, 2007, David Nebrada - szaleństwo sztuki czy sztuka szaleństwa, w: Światło i mrok. Eseje o fotografi hiszpańskiej, Tomasz Ferenc, Janina Studzińska (red.), Fundacja Edukacji Wizualnej, Łódź.

Welsch Wolfgang, 1999, Procesy estetyzacji. Zjawiska, rozróżnienia, perspektywy, w: Sztuka i estetyzacja. Studia teoretyczne, Krystyna Zamiara, Marian Golka (red.), Wydawnictwo Fundacji Humaniora, Poznań.

Wilk Eugeniusz, 2001, Przemoc ikoniczna czy „nowa widzialnośc”?, Wydawnictwo Uniwersytetu Śląskiego, Katowice.

Wolny-Zmorzyński Kazimierz, 2006, Fotografia prasowa - między etyka a sensacja, w: Między odpowiedzialnościa a sensacją. Dziennikarstwo i edukacja na przełomie wieków, Kazimierz Wolny-Zmorzyński, Marta Wrońska, Wojciech Furman (red.), Wydawnictwo Uniwersytetu Rzeszowskiego, Rzeszów. 


\section{SEEN THROUGH THE CAMERA - THE SEMIOLOGY OF DEPICTIONS OF VIOLENCE}

\section{Summary}

The article contains an attempt to analyse the phenomenon of visual violence (iconic) distributed by mass media, like photography, the cinema, television documentaries and news and the Internet. The authors attempt to demonstrate the characteristics of ths type of violence, referring to specific examples, which are interpreted according to the concepts of George Gerbner, Erich Fromm, Susan Sontag, Jean Baudrillard and others. The contemporary iconosphere encourages the practice of the mechanical approach to looking at violence, separating it from ethical reflections, which is why the question of screen violence, on the consequences of rapid but superficial information, seems still worth posing.

\section{Key words/słowa kluczowe}

visual violence (iconic) / przemoc wizualna (ikoniczna); pictures of war / obrazy wojny; photography / fotografia; mass media / media masowe; infotainment/infotainment; iconosphere / ikonosfera 